\title{
CORRECTION
}

\section{Correction to: Establishment of Punica granatum L. peel cell culture to produce bioactive compounds}

\author{
Lior Rubinovich $^{1}$ (1) $\cdot$ Barak Segev $^{2,3} \cdot$ Rida Habashi $^{2,3} \cdot$ Pazit Con $^{2} \cdot$ Rachel Amir $^{2,3}$
}

Published online: 16 May 2019

(c) Springer Nature B.V. 2019

\section{Correction to: \\ Plant Cell, Tissue and Organ Culture (PCTOC) https://doi.org/10.1007/s11240-019-01609-3}

In the initial, online publication, the authors' given names were captured as family names and vice versa. The names are correctly shown here. The original article has been corrected.
Publisher's Note Springer Nature remains neutral with regard to jurisdictional claims in published maps and institutional affiliations.

The original article can be found online at https://doi.org/10.1007/ s11240-019-01609-3.

Lior Rubinovich

liorr@migal.org.il

1 Northern R\&D, MIGAL - Galilee Research Institute, P.O.

Box 831, 11016 Kiryat Shmona, Israel

2 MIGAL - Galilee Research Institute, P.O. Box 831,

11016 Kiryat Shmona, Israel

3 Tel Hai College, Upper Galilee, 12210 Kiryat Shmona, Israel 